\title{
Grassland communities of urban open spaces in Bloemfontein, Free State, South Africa
}

\begin{tabular}{|c|c|}
\hline \multicolumn{2}{|c|}{$\begin{array}{l}\text { Authors: } \\
\text { Mamokete N.V. Dingaan }{ }^{1,2} \\
\text { Pieter J. du Preez }{ }^{1}\end{array}$} \\
\hline \multicolumn{2}{|c|}{$\begin{array}{l}\text { Affiliations: } \\
{ }^{1} \text { Department of Plant } \\
\text { Sciences, University of the } \\
\text { Free State, South Africa }\end{array}$} \\
\hline \multicolumn{2}{|c|}{$\begin{array}{l}\text { ²Department of Soil, Crop } \\
\text { and Climate Sciences, } \\
\text { University of the Free State, } \\
\text { South Africa }\end{array}$} \\
\hline \multicolumn{2}{|c|}{$\begin{array}{l}\text { Correspondence to: } \\
\text { Mamokete Dingaan }\end{array}$} \\
\hline \multicolumn{2}{|c|}{$\begin{array}{l}\text { Email: } \\
\text { mdingaan@gmail.com }\end{array}$} \\
\hline \multicolumn{2}{|c|}{$\begin{array}{l}\text { Postal address: } \\
\text { PO Box 339, Bloemfontein } \\
9300 \text {, South Africa }\end{array}$} \\
\hline \multicolumn{2}{|c|}{$\begin{array}{l}\text { Dates: } \\
\text { Received: } 15 \text { Feb. } 2012 \\
\text { Accepted: } 20 \text { Sept. } 2012 \\
\text { Published: } 14 \text { Mar. } 2013\end{array}$} \\
\hline \multicolumn{2}{|c|}{$\begin{array}{l}\text { How to cite this article: } \\
\text { Dingaan, M.N.V. \& Du } \\
\text { Preez, P.J., 2013, 'Grassland } \\
\text { communities of urban open } \\
\text { spaces in Bloemfontein, Free } \\
\text { State, South Africa', Koedoe } \\
\text { 55(1), Art. \#1075, } 8 \text { pages. } \\
\text { http://dx.doi.org/10.4102/ } \\
\text { koedoe.v55i1.1075 }\end{array}$} \\
\hline \multicolumn{2}{|c|}{$\begin{array}{l}\text { Note: } \\
\text { Additional supporting } \\
\text { information may be found } \\
\text { in the online version of } \\
\text { this article as an Online } \\
\text { Appendix: http://dx.doi. } \\
\text { org/10.4102/koedoe. } \\
\text { v55i1.1075-1. }\end{array}$} \\
\hline \multicolumn{2}{|c|}{$\begin{array}{l}\text { (C) 2013. The Authors. } \\
\text { Licensee: AOSIS } \\
\text { OpenJournals. This work } \\
\text { is licensed under the } \\
\text { Creative Commons } \\
\text { Attribution License. }\end{array}$} \\
\hline \multicolumn{2}{|l|}{ Read online: } \\
\hline 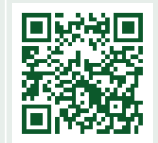 & $\begin{array}{l}\text { Scan this QR } \\
\text { code with your } \\
\text { smart phone or } \\
\text { mobile device } \\
\text { to read online. }\end{array}$ \\
\hline
\end{tabular}

Natural vegetation in urban environments is greatly impacted by human activities and it is in constant threat of degradation and destruction as a result of urbanisation. This vegetation, although fragmented, serves an important ecological function and needs to be properly managed and conserved. Studies on urban vegetation are lacking in South Africa, with only a handful having been carried out since the end of the last century. This study was initiated to identify, classify and describe the grassland communities of the urban open spaces in Bloemfontein. Relevés were compiled in 61 sample plots, where species present and habitat information were recorded. Care was taken to restrict sample plots to vegetation in pristine condition, wherever possible, and severely degraded stands were avoided. A two-way indicator species analysis (TWINSPAN) classification, refined by Braun-Blanquet procedures, revealed two distinct major communities, seven communities and four sub-communities. Both detrended and canonical correspondence analyses indicated the vegetation units to be associated with soil texture and $\mathrm{pH}$, although biotic factors such as overgrazing, burning and mowing also influence the composition of the vegetation. The proper management and conservation of urban open spaces requires in-depth knowledge of the spatial distribution, floristic, structural and functional compositions within the major vegetation types in this environment. The present study further contributed towards formulating ways for the proper management, utilisation and functioning of the open spaces within the Bloemfontein area.

Conservation implications: The Grassland Biome of South Africa is poorly conserved, mainly because of its status as an agricultural hub of the country. The preservation of natural and semi-natural forms of urban vegetation is important because such vegetation, although often disturbed and degraded, could form dispersal corridors between peri-urban and rural vegetation.

\section{Introduction}

Bloemfontein lies within the Grassland Biome (Rutherford \& Westfall 1994) and is classified by Acocks (1988) as part of the Dry Cymbopogon - Themeda Veld (VT 50). Here Themeda triandra is ecologically the most important grass, both to wild and domestic animals, and is the most widely distributed of the climax grasses. One of the key environmental variables affecting the functioning of the grassland ecosystem globally is rainfall variability (Tilman \& El Haddi 1992). Bloemfontein is situated in a semi-arid region, where precipitation is low and highly variable (Noy-Meir 1973; Sala \& Lauenroth 1982). Although semi-arid regions typically receive substantial precipitation for at least a few months of the year, lack of adequate rainfall for many months may also prevail (Bailey 1979).

The Grassland Biome of South Africa is an important agricultural region, especially for the intensive production of crops such as maize and wheat (Department of Agriculture, Forestry and Fisheries 2010). It is also important for extensive stock farming; mainly for dairy, beef and wool production. However, the intensive crop production and livestock grazing pressure have resulted in the destruction or degradation of large portions of pristine vegetation in the biome. In addition, natural and semi-natural vegetation is constantly impacted by urban development and, according to Low and Rebelo (1996), many of the natural areas in the biome have been lost as a result of urbanisation. In recognition of the poor conservation status of the biome, Cohen and Hugo (1986) emphasise the importance of conservation outside officially designated nature reserves, such as in urban open spaces.

In the vicinity of Bloemfontein, as in many areas of the biome, natural vegetation is represented by small fragmented areas. This fragmentation of previously intact natural environments may cause the potential loss of habitat for some species, the isolation of other species on natural remnants within the urban environment and even the total extinction of certain plant species (Wood et al. 1994). 
Studies of urban vegetation in South Africa are lacking and only a limited number of vegetation surveys have been carried out in these areas: for example, in Durban, KwaZulu-Natal Province (Roberts 1993); Potchefstroom, North West Province (Cilliers, Van Wyk \& Bredenkamp 1999); Klerksdorp, North West Province (Van Wyk, Cilliers \& Bredenkamp 2000); and Pretoria, Midrand, Johannesburg and parts of the West Rand, Gauteng Province (Grobler, Bredenkamp \& Brown 2006). The aim of this study was therefore to identify, classify and describe the grassland communities of the natural open areas in Bloemfontein.

\section{Research method and design Study area}

The study was carried out in natural open spaces within the Bloemfontein metropolitan area, which include the inner city area, as well as the surrounding farms and smallholdings. The study area extends from approximately $29^{\circ} 00^{\prime} \mathrm{S}$ to $29^{\circ} 15^{\prime} \mathrm{S}$ and $26^{\circ} 07^{\prime} \mathrm{E}$ to $26^{\circ} 21^{\prime} \mathrm{E}$, at an altitude of $1350 \mathrm{~m}$ a.s.l. $-1450 \mathrm{~m}$ a.s.l.

There are various large open spaces in the area, but, for this study, special emphasis was placed on the natural and semi-natural areas. These areas are fragmented and are most prominent towards the periphery of the city. They comprise numerous hills and ridges, areas along drainage lines and uncultivated patches on smallholdings and farms. Other open spaces studied were vacant residential lots and the yetto-be-developed areas as indicated in the spatial development framework of the Mangaung Metropolitan Municipality (2011). Green belts adjacent to railway lines and main roads were also included in the study because they form part of the natural open space system within the Bloemfontein area, but the open spaces in the inner city area, such as parks and sports grounds, were excluded from the study as they were fully transformed.

According to the Köppen climate classification system, Bloemfontein falls under the BSk climate zone (Schulze 1947). This is a Steppe climate in which the winters are dry and the mean annual temperature is below $18.0^{\circ} \mathrm{C}$ (Le Houérou, Poppov \& See 1993; Schulze \& McGee 1978). Maximum temperatures are recorded in December and January, averaging $30.1^{\circ} \mathrm{C}$ and $30.6^{\circ} \mathrm{C}$, respectively (Figure 1). Below zero temperatures are often recorded for June $\left(-1.0^{\circ} \mathrm{C}\right)$ and July $\left(-1.2{ }^{\circ} \mathrm{C}\right)$. The annual mean maximum temperature is $24.6^{\circ} \mathrm{C}$ and the annual mean minimum temperature is $7.6^{\circ} \mathrm{C}$, with the average annual temperature of $16.1{ }^{\circ} \mathrm{C}$. Rain mainly falls during the summer months, often in the form of thunderstorms. The average annual rainfall is $550 \mathrm{~mm}$.

Three different land types are distinguished in the study area, namely the Ca, Dc and Ea land types. Within each of these land types, soils vary from sandy to clayey, as a result of the variation in parent material. The Ca land type, occurring as Ca8 and Ca22 subdivisions, is a mixture of duplex and plinthic soils. The Ca8 subdivision is found on the western part of the study area and consists mainly of sandy Hutton-
Bainsvlei soils and more clayey Valsrivier-Swartland soils; the Ca22 subdivision occurs in the south and is mainly dominated by Valsrivier soils. The Dc land type occurs as subdivision Dc13, which is dominated by duplex soils of the Valsrivier-Swartland-Sterkspruit forms. It is only present in small pockets in the eastern part of the study area. The Ea land type is found in the central and northern parts and occurs as subdivision Ea39, the most extensive in the study area. It consists mainly of sandy Oakleaf soils, although a mixture of the clayey Milkwood, Arcadia and Valsrivier soils are also prominent. The dominant soil profiles are described according to Land Type Survey Staff (1993) and the soil forms and series are used according to the Soil Classification Working Group (1991).

The geologic formations of the study area belong to the Karoo Supergroup and consist of the Tierberg Formation of the Ecca Group and the Adelaide Sub-Group of the Beaufort Group, as well as dolerite intrusions of the post-Karoo age (Johnson et al. 2006).

\section{Vegetation sampling and data analysis}

Relevés were compiled in 61 sample plots, each fixed at $16 \mathrm{~m}^{2}$. Care was taken to restrict sample plots to vegetation in pristine condition, wherever possible, and severely degraded stands were avoided. In each sample plot, all vascular plants present were recorded and all plant nomenclature was used according to Germishuizen and Meyer (2003). The cover-abundance values of all species present were allocated according to the Braun-Blanquet scale, as given by Mueller-Dombois and Ellenberg (1974), as well as Kent and Coker (1996). Habitat parameters recorded included soil depth, rockiness of the soil surface and the presence of biotic influences such as trampling and grazing. A total of 25 soil samples was collected and analysed for $\mathrm{pH}$, organic matter and texture. No soil samples were collected at one part of the study area, the Kwaggafontein hills, as this is a conservation area and no permission was granted to collect such samples.

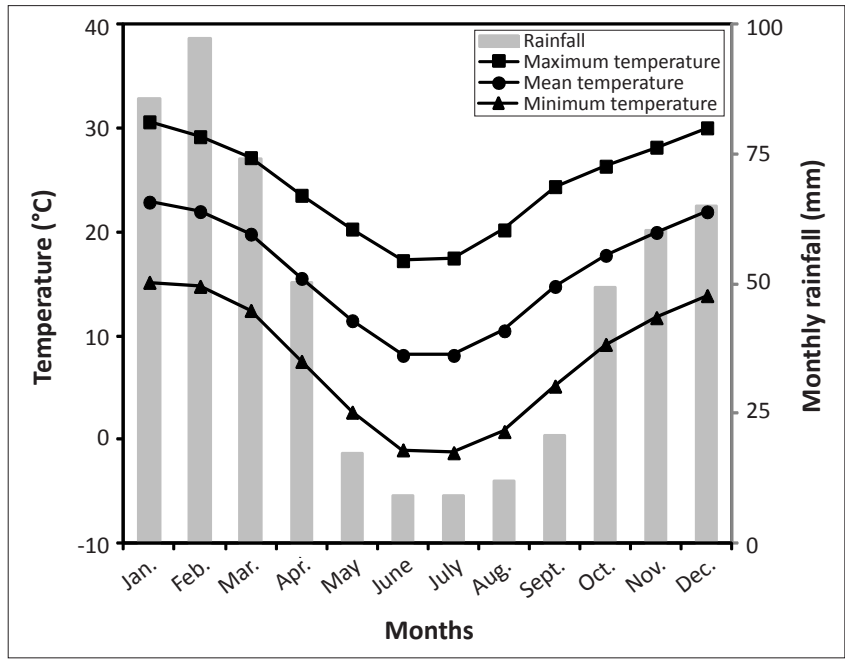

FIGURE 1: Long-term (1951-2000) meteorological data of the Bloemfontein Airport $\left(29^{\circ} 06^{\prime} \mathrm{S}, 26^{\circ} 18^{\prime} \mathrm{E}, 1351 \mathrm{~m}\right.$ a.s.l.), sourced from the South African Weather Service. 
The vegetation and habitat data were first captured into the TURBOVEG database (Hennekens 1996a) and then imported to MEGATAB (Hennekens 1996b), a visual editor for phytosociological tables, where the first approximation of the vegetation classification was obtained by the application of the two-way indicator species analysis (TWINSPAN) (Hill 1979a). Further refinement of the initial classification results was subsequently conducted within the MEGATAB programme, resulting in a phytosociological table. The relationships between the plant communities and environmental variables were determined by an ordination algorithm, detrended correspondence analysis (DCA) (Hill $1979 \mathrm{~b}$ ) and also by an extension of DCA, the canonical correspondence analysis (CCA) (Ter Braak \& Šmilauer 2009).

\section{Results \\ Vegetation classification}

The grassland communities of the Bloemfontein area are classified as Bloemfontein Dry Grassland by Mucina et al. (2006) The vegetation is dominated by T. triandra, a companion species with a wide ecological amplitude and Eragrostis lehmanniana as a typical associate. Other constantly present grasses are Eragrostis curvula and Digitaria eriantha. The forbs Oxalis depressa, Nidorella resedifolia and Hibiscus pusillus are of widespread occurrence, although they are hardly prominent (see Online Appendix). The habitats occupied by each of the communities are, by and large, distinguished by differences in soil depth, texture and $\mathrm{pH}$ (Table 1). Biotic factors, especially livestock grazing practices, also influence the composition of the communities.

The classification resulted in two major communities, which are grouped into seven communities and four subcommunities. The hierarchical classification of the plant communities is as follows:

1. Felicia muricata - Themeda triandra major community 1.1. Panicum coloratum - Digitaria eriantha community 1.1.1. Cyperus usitatus - Digitaria eriantha sub-community 1.2. Eragrostis obtusa - Sporobolus fimbriatus community 1.2.1. Panicum schinzii - Themeda triandra sub-community 1.3. Eragrostis biflora - Themeda triandra community
2. Aristida congesta - Themeda triandra major community

2.1. Trichoneura grandiglumis - Rhynchosia nervosa community 2.1.1. Conyza bonariensis - Eragrostis curvula subcommunity

2.1.2. Antephora pubescens - Digitaria argyrograpta subcommunity

2.2. Eragrostis trichophora-Cyperus capensis community

2.3. Hyparrhenia hirta - Themeda triandra community

2.4. Melinis repens - Eragrostis lehmanniana community.

\section{Vegetation description}

\section{Felicia muricata - Themeda triandra major community}

This widespread grassland community is mainly associated with low-lying, flat open plains where the soils are generally sandy clay loam, with the clay content ranging between $18.5 \%$ and $27.0 \%$ (Table 1 ). The vegetation has a uniform representation of grasses, with forbs and rarely shrubs interspersed between them. The two climax grasses T. triandra and $D$. eriantha (Species group N) have a characteristically high presence, indicating good veld condition. This is further indicated by the notable poor occurrence of the pioneer grass $A$. congesta and the sub-climax grass Eragrostis superba (Species group G), which are known to occur in disturbed veld. Other well represented species include Eragrostis chloromelas, F. muricata (Species group A) and E. lehmanniana (Species group N). This major community has six diagnostic species: namely, Indigofera alternans, Pentzia globosa, Tripteris aghillana, Schkuhria pinnata, E. chloromelas and F. muricata (Species group A). Three communities are recognised within this major community.

\subsection{Panicum coloratum - Digitaria eriantha community}

This grassland community is situated on flat plains on the city margins and also on fragmented natural areas between and within residential areas. It is differentiated and dominated by the grass species P. coloratum and Eragrostis plana (Species group B). Other equally prominent grasses are E. chloromelas (Species group A), T. triandra, E. lehmanniana, Aristida adscensionis and D. eriantha (Species group N). This community has a low number of species, with an average of only 11 recorded per sample plot. One sub-community is

TABLE 1: Soil characteristics of the grassland communities of the Bloemfontein area (mean values).

\begin{tabular}{|c|c|c|c|c|c|c|c|}
\hline \multirow{2}{*}{$\begin{array}{l}\text { Community or } \\
\text { sub-community }\end{array}$} & \multirow{2}{*}{$\begin{array}{l}\text { Number of } \\
\text { samples }^{b}\end{array}$} & \multirow[t]{2}{*}{ Depth (mm) } & \multirow[t]{2}{*}{$\mathrm{pH}$} & \multirow{2}{*}{$\begin{array}{c}\text { Organic } \\
\text { matter }(\%)\end{array}$} & \multicolumn{3}{|c|}{ Texture (\%) } \\
\hline & & & & & Clay & Silt & Sand \\
\hline 1.1.1. & 2 & 295 & 6.5 & 0.71 & 18.5 & 13.4 & 68.1 \\
\hline 1.1.2. & 3 & 253 & 6.9 & 1.23 & 27.0 & 10.7 & 62.3 \\
\hline 1.2.1. & 5 & 215 & 6.5 & 0.87 & 21.3 & 13.4 & 65.3 \\
\hline 1.2 .2 & 4 & 228 & 6.4 & 1.04 & 24.2 & 13.9 & 61.9 \\
\hline 1.3. & 2 & 320 & 6.7 & 0.95 & 18.5 & 9.2 & 72.3 \\
\hline 2.1.1. & 3 & 277 & 6.7 & 0.50 & 9.0 & 5.4 & 85.6 \\
\hline 2.1.2. & - & - & - & - & - & - & - \\
\hline 2.2 . & 2 & 355 & 5.9 & 0.52 & 13.2 & 10.2 & 76.6 \\
\hline 2.3. & 2 & 205 & 7.2 & 1.24 & 15.7 & 17.2 & 67.1 \\
\hline 2.4. & 2 & 225 & 7.9 & 0.38 & 12.0 & 18.9 & 69.1 \\
\hline
\end{tabular}

1.1.1., Cyperus usitatus - Digitaria eriantha sub-community; 1.1.2., unspecified; 1.2.1., Panicum schinzii - Themeda triandra sub-community; 1.2.2., unspecified; 1.3., Eragrostis biflora - Themeda triandra community; 2.1.1., Conyza bonariensis - Eragrostis curvula sub-community; 2.1.2., Antephora pubescens - Digitaria argyrograpta sub-community; 2.2., Eragrostis trichophora - Cyperus capensis community; 2.3., Hyparrhenia hirta - Themeda triandra community; 2.4., Melinis repens - Eragrostis lehmanniana community.

a, Number of the soil samples were collected for 25 selected relevés.

$b$, No data available for Antephora pubescens - Digitaria argyrograpta sub-community. 
recognised within the community, which is differentiated by its relatively high soil moisture.

\subsubsection{Cyperus usitatus - Digitaria eriantha sub-community}

This grassland community can be found occurring on flat open plains on the southern part of the study area. It is differentiated by species from group C, namely C. usitatus and Anthospermum rigidum subsp. pumilum. This sub-community is dominated entirely by grasses, with only a handful of forbs showing a rare occurrence. The most prominent grasses are E. chloromelas (Species group A), P. coloratum (Species group B), T. triandra, A. adscensionis and D. eriantha (Species group N). The only forb with a strong presence is $C$. usitatus (Species group C), whilst T. aghillana (Species group A) and $O$. depressa (Species group $\mathrm{N}$ ) are constantly present, but never prominent. An average of 13 species per sample plot was recorded.

\subsection{Eragrostis obtusa - Sporobolus fimbriatus community}

This community is found in pasture areas in the south of Bloemfontein, as well as towards the west of the city. It is dominated entirely by grasses, most notably Eragrostis obtusa and S. fimbriatus, which are also the diagnostic species (Species group D). Other equally dominant grasses are T. triandra and D. eriantha (Species group N), with F. muricata (Species group A), H. pusillus and Selago densiflora (Species group N) found occurring consistently within the community, but never prominently. An average of 13 species per sample plot was recorded, and one sub-community is recognised within this community.

\subsubsection{Panicum schinzii - Themeda triandra sub-community}

This is a sub-community found on the grassland plains and footslopes of the gently sloping small hills of the southern part of the study area. Grasses are dominant, the most prominent being E. obtusa, S. fimbriatus (Species group D), P. schinzii (Species group E), T. triandra, E. lehmanniana, E. curvula and D. eriantha (Species group N). The only forbs of prominent occurrence are F. muricata (Species group A), Conyza podocephala (Species group E) and Helichrysum dregeanum (Species group N). The diagnostic species for the sub-community are P. schinzii, Argemone ochroleuca, Monsonia angustifolia, C. podocephala, Chloris virgata and Nenax microphylla (Species group E). An average of 14 species per sample plot was recorded.

\subsection{Eragrostis biflora - Themeda triandra community}

This community is associated with open grasslands on the periphery of the western suburbs of Bloemfontein. The diagnostic species are the shade-loving grass Eragrostis biflora, the erect perennial herb Cyperus obtusiflorus, the karroid shrub Lycium cinereum and the highly palatable grass Digitaria tricholaenoides (Species group F). The grassland is dominated by I. alternans, P. globosa (Species group A), E. biflora (Species group F), T. triandra and E. lehmanniana (Species group N). This community has the lowest species richness of all the grassland communities of the Bloemfontein area, with an average of only eight species per sample plot recorded.

\section{Aristida congesta - Themeda triandra major community}

This widespread community represents grasslands that are characterised by sandy loam soils. The sand content ranges between $67.1 \%$ and $85.6 \%$ (Table 1 ). It is mainly found in the northern and western homesteads and farming areas and, to a smaller extent, on the smallholdings to the east of Bloemfontein. The most dominant species in the community is T. triandra (Species group N), with other grasses such as A. congesta, E. superba (Species group G) and E. lehmanniana (Species group N) also prominent. The diagnostic species for the community are A. congesta and E. superba (Species group G), grasses which are also indicators of veld disturbance. Four communities are recognised within this major grassland.

\subsection{Trichoneura grandiglumis - Rhynchosia nervosa community}

This is a community situated on the western part of the study area. It occurs on the sides of the Kwaggafontein hills and also on the grass plains at the Tempe Airfield. Seven diagnostic species are identified for the community: the grasses T. grandiglumis, Pogonarthria squarrosa and Heteropogon contortus and the forbs $R$. nervosa, Pollichia campestris, Moraea pallida and Senecio burchellii (Species group $\mathrm{H}$ ). This community is partially dominated by the highly palatable grasses E. superba (Species group G) and T. triandra (Species group N) and the less palatable $A$. congesta (Species group G), T. grandiglumis, $P$. squarrosa, $H$. contortus (Species group $\mathrm{H}$ ) and E. lehmanniana (Species group N). Other constantly present species are $R$. nervosa (Species group H), O. depressa, S. densiflora and H. dregeanum (Species group N). Two sub-communities are recognised within this grassland community.

\subsubsection{Conyza bonariensis - Eragrostis curvula sub- community}

This is a sub-community occurring on the north-western part of the study area, particularly at the Tempe Airfield and the neighbouring skydiving ground. The perennial grasses A. congesta (Species group G), T. grandiglumis (Species group $\mathrm{H}$ ), T. triandra and E. curvula (Species group $\mathrm{N}$ ) are dominant. Other species of notable occurrence include R.nervosa (Species groupH), C. bonariensis (Species groupI) and $S$. densiflora (Species group N). The diagnostic species are Salvia verbenaca, Aristida canescens and C. bonariensis (Species group I), whilst the strong presence of E. curvula and D. eriantha (Species group N) further distinguishes the subcommunity from the $A$. pubescens $-D$. argyrograpta subcommunity. An average of 13 species per sample plot was recorded.

\subsubsection{Antephora pubescens - Digitaria argyrograpta sub- community}

This sub-community is situated at the Kwaggafontein hills, a conservation area on the western part of the study area. It occurs on the gently undulating sides of the hills, as well as on the adjacent bottomland area on deep, red sandy soils, with little or no surface rock. Because this vegetation unit 
occurs in a conservation area, it is in primary condition and protected from the effects of grazing. It also has the highest species richness, with an average of 30 species per sample plot and the highest number of diagnostic species (20). Some diagnostic species include: the grasses $A$. pubescens, D. argyrograpta, Aristida stipitata, Tragus koeleroides and Cynodon dactylon, the herbs Gazania krebsiana, Commelina africana, Harpagophytum procumbens and Dicoma macrocephala and the karroid shrub Chrysocoma ciliata (Species group J). The vegetation consists of a wide variety of grass species, of which the most dominant is A. pubescens (Species group J). Its abundance is regarded as an indicator of good veld condition (Van Oudtshoorn 1999). Other prominent grasses are A. congesta and E. superba (Species group G), T. grandiglumis, $P$. squarrosa, and $H$. contortus (Species group $H$ ), $D$. argyrograpta and $A$. stipitata (Species group J), T. triandra and E. lehmanniana (Species group N), whilst $P$. campestris (Species group H), S. densiflora and H. dregeanum (Species group $\mathrm{N}$ ) are amongst the dominant forbs.

\subsection{Eragrostis trichophora - Cyperus capensis community}

This plant community occurs on the smallholdings of the eastern city margin. Species from group K differentiate the community: namely, the grasses E. trichophora and Eragrotis gummiflua, the sedge $C$. capensis, the perennial dwarf shrub Selago albida and the herb Crotalaria sphaerocarpa. These diagnostic species are also the most dominant, with A. congesta (Species group $\mathrm{G}$ ) being the only other spe cies of prominent occurrence. It replaces T. triandra (Species group $\mathrm{N}$ ) in some overgrazed patches. Only a limited number of species is present in this community and an average of only 11 species per sample plot was recorded.

\subsection{Hyparrhenia hirta - Themeda triandra community}

This is a community occurring along the roadsides at the northern margin of the city, where the soil is slightly gravelly. The tall, tufted perennial $H$. hirta (Species group L) is the only diagnostic species and entirely dominates, sometimes growing to heights exceeding $1 \mathrm{~m}$. The other prominent species in this community are the grasses T. triandra, E. lehmanniana and E. curvula (Species group N). An average of 11 species per sample plot was recorded.

\subsection{Melinis repens - Eragrostis lehmanniana community}

This is a slightly disturbed community occurring on roadsides on the western and north-western part of the study area. The soil along the roads where this community is found is, in general, gravelly, at times with small stones also found. This is largely a grass community, with Rhus lancea (Species group $\mathrm{M}$ ) the only woody species and T. aghillana (Species group A) being the only forb of notable occurrence. The most dominant grasses include $M$. repens and Enneapogon cenchroides (Species group M), T. triandra and E. lehmanniana (Species group N). E. cenchroides characteristically grows in clumps and, together with $M$. repens, dominates in disturbed patches, especially where the soils are exceptionally deep. The diagnostic species for this community are $M$. repens, E. cenchroides, $R$. lancea and Fingerhuthia africana
(Species group M). An average of 12 species per sample plot was recorded.

\section{Ordination}

The DCA analysis complements the classification in the Online Appendix and reveals distinct discontinuities between the communities (Figure 2). The CCA ordination of sample plots and soil variables (Figure 3) illustrates that

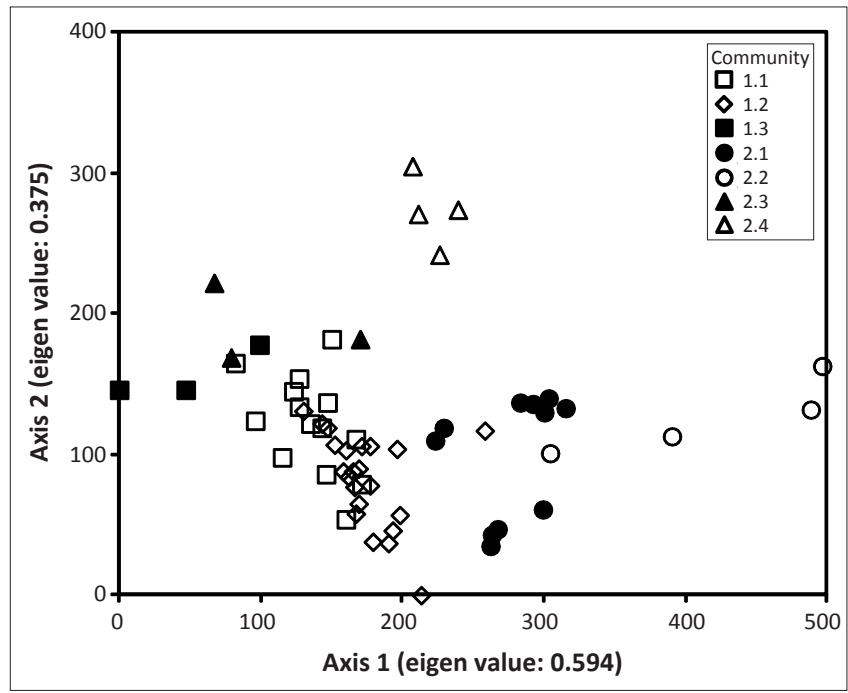

FIGURE 2: A detrended correspondence analysis ordination of the grassland vegetation of Bloemfontein, showing the relative positions of the relevés along the first two axes (Axis 1 and Axis 2).

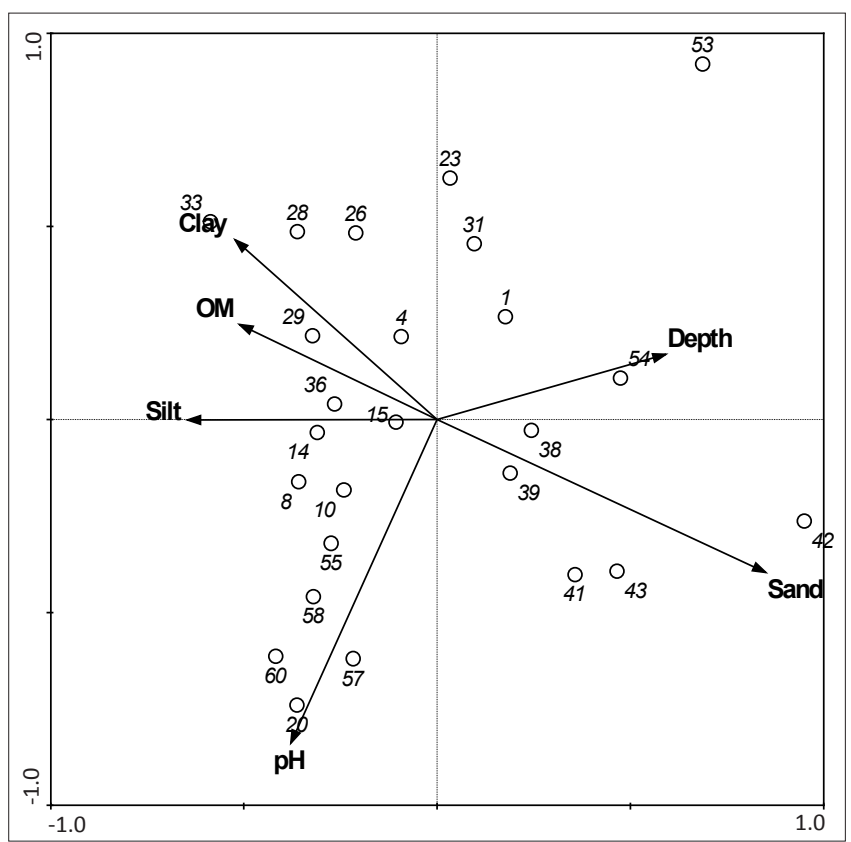

The soil variables are: Depth, soil depth; Clay, clay content; Silt, silt content; Sand, sand content; $\mathrm{OM}$, organic matter content, and $\mathrm{pH}$.

The numbers (in italics) in the biplot are same as relevés' numbers in the phytosociological table (see Online Appendix): Cyperus usitatus - Digitaria eriantha sub-community, 1, 4; sub-community 1.1 .2 (unspecified) - 8, 10, 14; Panicum schinzii - Themeda triandra subcommunity, 15, 20, 23, 26, 28; sub-community 1.2.2 (unspecified) - 29, 31, 33, 36; Eragrostis biflora - Themeda triandra community, 38, 39; Conyza bonariensis - Eragrostis curvula subcommunity, 41,42,43. Antephora pubescens - Digitaria argyrograpta sub-community, community, 41, 42, 43; Antephora pubescens - Digitaria argyrograpta sub-community, no data available; Eragrostis trichophora - Cyperus capensis community, 53, 54; Hyparrhenia hirta - Themeda triandra community, 55, 57; Melinis repens - Eragrostis lehmanniana
community, 58, 60 .

FIGURE 3: A canonical correspondence analysis biplot of 25 sample relevés and soil environment variables for the first two axes: Axis 1 (horizontal) and Axis 2 (vertical). 
communities of the F. muricata - T. triandra major community (Community 1) occur in soils with relatively high organic matter and clay content and slightly lower $\mathrm{pH}$ (i.e. neutral soils). Communities of the $A$. congesta $-T$. triandra major community (Community 2), on the other hand, are associated with more sandy soils that have less organic matter, but slightly higher $\mathrm{pH}$ (Table 1). There is a correlation between soil texture and organic matter content; organic matter is positively correlated with the clay content $(r=0.757$; $p<0.001)$ and negatively correlated with the sand content $(r=0.666 ; p<0.001)$.

The biplot of the species and soil environmental variables (Figure 4) further supports the assertion that species of the F. muricata - T. triandra major community (Species groups A, B, C, D, E) have a strong association with higher clay content and organic matter in the soil. Species from group $\mathrm{F}$, together with the character species of the communities of $A$. congesta - T. triandra major community (Species groups G, H, I, K) are strongly associated with the soil depth and sand gradients. In contrast, the other character species of the A. congesta T. triandra major community, namely $H$. hirta (Species group L), M. repens, E. cenchroides and F. africana (Species group M) are strongly associated with the $\mathrm{pH}$ gradient. These species

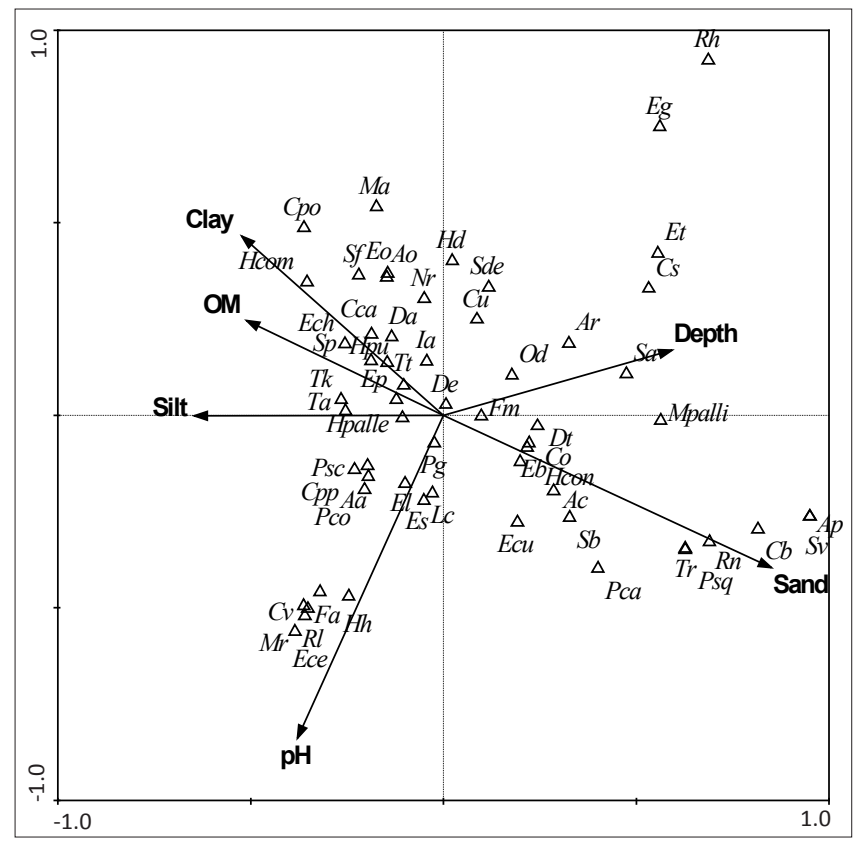

The soil variables are Depth, soil depth; Clay, clay content; Silt, silt content; Sand, sand content; $\mathrm{OM}$, organic matter content, and $\mathrm{pH}$.

The species' names in the biplot are abbreviated as: Group A in the phytosociological table (see Online Appendix), Ech, Eragrostis chloromelas; Fm, Felicia muricata; Ia, Indigofera (see Online Appendix), Ech, Eragrostis chloromelas; Fm, Felicia muricata; la, Indigofera alternans; Pg, Pentzia globosa; Sp, Schkuhria pinnata; Ta, Tripteris aghillana; Group B,
Ep. Eragrostis plana; Pco, Panicum coloratum; Group C, Ar, Anthospermum rigidum s. pumilum; Cu, Cyperus usitatus; Group D, Eo, Eragrostis obtusa; Sf, Sporobolus fimbriatus, Group E, Ao, Argemone ochroleuca; Cpo, Conyza podocephala; Cv, Chloris virgata; Ma, Monsonia angustifolia; Psc, Panicum schinzii; Group F, Co, Cyperus obtusiflorus; Dt, Digitaria tricholaenoides; Eb, Eragrostis biflora; Lc, Lycium cinereum; Group G, Ac, Aristida congesta; Es, Eragrostis superba; Group H, Hcon, Heteropogon contortus; Mpalli, Moraea pallida; Pca, Pollichia campestris; Psq, Pogonarthria squarrosa; Rn, Rhynchosia nervosa; Sb, Senecio burchellii; Tr, Trichoneura grandiglumis; Group I, Cb, Conyza bonariensis; Sv, Salvia verbenaca; Group J, Ap, Anthephora pubescens; Cpp, Cymbopogon pospischilii; Da, Digitaria argyrograpta; Hcom. Hermannia comosa; Hpalle, Hertia pallens; Rh, Ruschia hamata; TK, Tragus koelerioides: Group K, Cca, Cyperus capensis; Cs, Crotalaria sphaerocarpa; Eg Tk, Tragus koelerioides; Group K, Cca, Cyperus capensis; Cs, Crotalaria sphaerocarpa; Eg Eragrostis gummiflua; Et, Eragrostis trichophora; Sa, Selago albida; Group L, Hh, Hyparrhenia hirta; Group M, Ece, Enneapogon cenchroides; Fa, Fingerhuthia africana, Mr, Melinis repen Rl, Rhus lancea, Group N, Aa, Aristida adscensionis; De, Digitaria eriantha, Ecu, Eragrostis curvula, El, Eragrostis lehmanniana; $\mathrm{Hd}$, Helichrysum dregeanum; Hpu, Hibiscus pusillus; $N$ Nidorella resedifolia; Od, Oxalis depressa; Sde, Selago densiflora; Tt, Themeda triandro.

FIGURE 4: A canonical correspondence analysis biplot of 59 plant species and soil environment variables for the first two axes: Axis 1 (horizontal) and Axis 2 (vertical). are commonly found on gravelly soil (Van Oudtshoorn 1999) and, in the study area, they are often located along roadsides and in road reserves. The only woody character species, $R$. lancea (Species group M), is also strongly associated with the $\mathrm{pH}$ gradient and it often prefers calcareous substrates (Van Wyk \& Van Wyk 1997).

\section{Trustworthiness}

The classification of the grassland communities of Bloemfontein is based on data acquired through human observations and requires consideration of the trustworthiness of the data in the contexts below.

\section{Reliability}

The nature of this study does not require repeated surveys and therefore the authors were able to satisfactorily draw conclusions from their research findings because they believe they have utilised the most widely used and arguably the most efficient of all types of vegetation sampling techniques. A potential bias, however, can arise during the vegetation classification but this is compensated for by the use of computer programmes such as TWINSPAN, DECORANA and CANOCO.

\section{Validity}

The authors believe the methodologies employed were successful at achieving the objectives of the study.

\section{Discussion}

The classification of the grasslands of the urban open spaces in Bloemfontein revealed the existence of seven identifiable plant communities and four sub-communities, all represented within two major communities. The vegetation can be broadly classified as the T. triandra - E. lehmanniana grassland, where T. triandra is the dominant sweet grass. Other major grasses include E. lehmanniana, E. curvula, $D$. eriantha and E. chloromelas. Out of a total of 119 species recorded for the study area, 64 play a diagnostic role, 10 are companion species and a further 45 are either localised or of very rare occurrence. The distribution and composition of the plant communities are linked with habitat factors such as soil depth and texture, rockiness of the soil surface and habitat disturbance (especially utilisation by livestock).

The results of the soil analysis indicate a correlation between soil texture and organic matter content, whereby organic matter is positively correlated with the clay content and negatively correlated with the sand content. These correlations can be explained in two ways. Firstly, soils with high clay content have a high water holding capacity and therefore high moisture content. Communities in such soils are, as a result, more productive; hence the high organic matter content in soil. Secondly, according to Foth (1990), clay plays a role in protecting organic matter decomposition, thus contributing towards the high organic matter content in the F. muricata - T. triandra major community. Communities 
of the A. congesta - T. triandra major community, on the other hand, occupy areas of higher sand content that are characterised by low soil moisture content as a result of low water holding capacity. These communities are therefore less productive and hence have less organic matter.

The distribution of species commonly found on gravelly soil along roadsides and in road reserves, such as $H$. hirta, $M$. repens, E. cenchroides and F. africana is strongly affected by $\mathrm{pH}$. The soils near and along roads are known to have higher $\mathrm{pH}$ levels; this is attributed to calcareous road dust and leachate (Auerbach, Walker \& Walker 1997; Johnston \& Johnston 2004).

Communities occurring on pasture land in farming areas show notable signs of overgrazing and trampling. There is also a tendency of selective grazing by livestock, through which animals over-utilise the palatable grasses. This results in the replacement of nutritious perennial grasses by annual grasses and weeds of inferior value. The invasion of the veld by the unpalatable species can have serious ecological implications because most of these invaders are a threat to the indigenous species. It is therefore necessary to manage the vegetation according to ecological principles in order to maintain optimum floristic composition and diversity.

Furthermore, there is a common practice of mowing or burning vegetation that grows along roads and railway tracks in the vicinity of residential and commercial areas. This vegetation, though disturbed and unstable, is vital simply because most of the natural vegetation in urban areas occurs in fragmented forms as a result of urbanisation (Florgård 2007). The disturbed areas could therefore form dispersal corridors between the natural fragments and, in this way, act as stepping-stones for a variety of plant species (Davis \& Glick 1978). The preservation of these disturbed areas may, in the end, offset the biological isolation of the natural areas and, in so doing, provide ecological continuity throughout the urban environment (Millard 2004; Poynton \& Roberts 1985).

\section{Conclusion}

The distribution and composition of the grassland communities of the Bloemfontein area are linked with habitat factors such as soil depth and texture, with the F. muricata - T. triandra major community associated with clayey soils and the $A$. congesta - T. triandra major community found on sandy soils. The communities are also impacted by habitat disturbance, mainly in the form of overgrazing, mowing and burning. This phenomenon is not unique to these grasslands, because large portions of pristine vegetation in the Grassland Biome of South Africa have been degraded and destroyed due to livestock grazing pressure and the ploughing of arable land. The proper management and conservation of urban open spaces requires in-depth knowledge of the spatial distribution, floristic, structural and functional compositions within the major vegetation types in the urban environment. The present vegetation study was initiated to contribute towards formulating ways for the proper functioning and management of the open spaces within the Bloemfontein Metropolitan area. The benefits of conserving urban vegetation are immense; scientifically, socially, and economically. Open space within urban areas has value upon urban microclimate, hydrology, biodiversity, and ecological processes (Nicholson-Lord 1987; Platt, Rowntree \& Muick 1994). This phytosociological study provides valuable information on the structure and composition of the vegetation of the Bloemfontein metropolitan area, which can be utilised by the relevant local and national authorities for environmental planning and conservation strategies for the area.

\section{Acknowledgements}

The assistance of the following persons is sincerely appreciated: Dr Pieter le Roux (University of the Free State) for his help in interpreting the soils and land types of the study area, Ms Yvonne Dessels and the Soil Science laboratory staff of the University of the Free State for the soil analysis, as well as the two anonymous reviewers for their useful comments and suggestions.

\section{Competing interests}

The authors declare that they have no financial or personal relationships which may have inappropriately influenced them in writing this article.

\section{Authors' contributions}

M.N.V.D. (University of the Free State) conducted the vegetation survey, data analysis and wrote the manuscript, P.J.d.P. (University of the Free State) conceptualised the project, conducted part of the vegetation survey and assisted with the vegetation classification.

\section{References}

Acocks, J.P.H., 1988, 'Veld types of South Africa', 3rd edn., Memoirs of the Botanical Survey of South Africa 57, 1-146.

Auerbach, N.A., Walker, M.D. \& Walker, D.A., 1997, 'Effects of roadside disturbance on substrate and vegetation properties in arctic tundra', Ecological Applications 7(1), 218-235. http://dx.doi.org/10.1890/1051-0761(1997)007[0218:EORDOS]2. 7(1), 218

Bailey, H.P. , 1979, 'Semi-arid climates: Their definition and distribution', in A.E. Hall, G.H. Cannell \& H.W. Lawton (eds.), Agriculture in semi-arid environments, pp. 73-97, Springer-Verlag, Berlin. http://dx.doi.org/10.1007/978-3-642-67328-3_3

Cilliers, S.S., Van Wyk, E. \& Bredenkamp, G.J., 1999, 'Urban nature conservation: Vegetation of natural areas in the Potchefstroom municipal area, North West Province, South Africa', Koedoe 42, 1-30. http://dx.doi.org/10.4102/koedoe. v42i1.218

Cohen, M. \& Hugo, M.L., 1986, 'Conservation outside of officially designated areas With emphasis on the urban environment', Parks and Grounds 38, 15-23.

Davis, A.M. \& Glick, T.F., 1978, 'Urban ecosystems and island biogeography', Environmental Conservation 5, 299-304. http://dx.doi.org/10.1017/S037689290000638X

Department of Agriculture, Forestry and Fisheries, 2010, Abstract of agricultural statistics, DAFF Directorate, Agricultural Statistics, Pretoria.

Florgård, C., 2007, 'Preserved and remnant natural vegetation in cities: A geographically divided field of research', Landscape Research 32, 79-94. http:// dx.doi.org/10.1080/01426390601097750

Foth, H.D., 1990, Fundamentals of soil science, 8th edn., John Wiley \& Sons, New York.

Germishuizen, G. \& Meyer, N.L. (eds.), 2003, 'Plants of southern Africa: An annotated checklist', Strelitzia 14, 1-1231.

Grobler, C.H., Bredenkamp, G.J. \& Brown, L.R., 2006, 'Primary grassland communities of urban open spaces in Gauteng, South Africa', South African Journal of Botany 72, 367-377. http://dx.doi.org/10.1016/j.sajb.2005.10.008 
Hennekens, S.M., 1996a, TURBOVEG: Software package for input, processing and presentation of phytosociological data, IBN-DLO, University of Lancaster.

Hennekens, S.M., 1996b, MEGATAB: A visual editor for phytosociological tables, Giesen \& Geurts, Ulft.

Hill, M.O., 1979a, TWINSPAN: A Fortran program for arranging multivariate data in an ordered two-way table by classification of individuals and attributes, Cornel University, New York.

Hill, M.O., 1979b, DECORANA: A Fortran program for detrended correspondence analysis and reciprocal averaging, Cornell University, New York.

Johnson, M.R., Van Vuuren, C.J., Visser, J.N.J., Cole, D.I., Wickens, H. de V., Christie, A.M.D. et al., 2006, 'Sedimentary rocks of the Karoo Super Group', in M.R. Johnson, C.R. Anhaeusser \& R.J. Thomas (eds.), The geology of South Africa, 2nd edn., The Geological Society of South Africa, Johannesburg.

Johnston, F.M. \& Johnston, S.W., 2004, 'Impacts of road disturbance on soil properties and on exotic plant occurrence in subalpine areas of the Australian alps', Arctic, Antarctic, and Alpine Research 36(2), 201-207. http://dx.doi.org/10.1657/15230430(2004)036[0201:IORDOS]2.0.CO;2

Kent, M. \& Coker, P., 1996, Vegetation description and analysis, 2nd edn., John Wiley \& Sons, London.

Land Type Survey Staff, 1993, 'Land types of the maps 2926 AA-Bloemfontein and 2926 AB-Maselspoort', Memoirs on the Agricultural Natural Resources of South Africa 14.

Le Houérou, H.N., Poppov, G.F. \& See, L., 1993, Agro-bioclimatic classification of Africa, Agrometereology Series Working Paper No. 6, Food and Agricultural Organization, Rome.

Low, A.B. \& Rebelo, A.G., 1996, Vegetation of South Africa, Lesotho and Swaziland, Department of Environmental Affairs and Tourism, Pretoria.

Mangaung Metropolitan Municipality, 2011, Integrated development plan review for 2011-2012, Mangaung Metropolitan Municipality, Bloemfontein.

Millard, A., 2004, 'Indigenous and spontaneous vegetation: Their relationship to urban development in the city of Leeds, UK', Urban Forestry \& Urban Greening 3 , 39-47. http://dx.doi.org/10.1016/j.ufug.2004.04.004

Mucina, L., Hoare, D.B., Lötter, M.C., Du Preez, P.J., Rutherford, M.C, Scott-Shaw, C.R. et al., 2006, 'Grassland Biome', in L. Mucina \& M.C. Rutherford (eds.), The vegetation of South Africa, Lesotho and Swaziland, Strelitzia 19, pp. 348-437, South African National Biodiversity Institute, Pretoria.

Mueller-Dombois, D. \& Ellenberg, H., 1974, Aims and methods of vegetation ecology, Wiley, New York.

Nicholson-Lord, D., 1987, The greening of the cities, Routledge \& Kegan Paul, London. http://dx.doi.org/10.4324/9780203392614
Noy-Meir, I., 1973, 'Desert ecosystems: Environment and producers', Annual Review of Ecology and Systematics 4, 25-51. http://dx.doi.org/10.1146/annurev. of Ecology and Syster

Platt, R.H., Rowntree, R.A. \& Muick, P.C., 1994, The ecological city: Preserving and restoring urban biodiversity, The University of Massachusetts Press, Amherst.

Poynton, J.C. \& Roberts, D.C., 1985, 'Urban open space planning in South Africa: A biogeographical perspective', South African Journal of Botany 81, 33-37.

Roberts, D.C., 1993, 'Vegetation ecology of municipal Durban, Natal: Floristic classification', Bothalia 23, 271-326.

Rutherford, M.C. \& Westfall, R.H., 1994, 'Biomes of southern Africa. An objective categorisation', 2nd edn., Memoirs of the Botanical Survey of South Africa 63, $1-94$.

Sala, O.E. \& Lauenroth, W.K., 1982, 'Small rainfall events: An ecological role in semiarid regions', Oecologia 53, 301-304. http://dx.doi.org/10.1007/BF00389004

Schulze, B.R., 1947, 'The climates of South Africa according to the classifications of Köppen and Thornwaite', South African Geographical Journal 29, 32-42. http:// dx.doi.org/10.1080/03736245.1947.10559253

Schulze, B.R. \& McGee, O.S., 1978, 'Climatic indices and classifications in relation to the biogeography of southern Africa', in M.J.A. Werger (ed.), Biogeography and ecology of southern Africa, pp. 19-52, W Junk, The Hague. http://dx.doi org/10.1007/978-94-009-9951-0_2

Soil Classification Working Group, 1991, 'Soil classification: A taxonomic system for South Africa', Memoirs on the Agricultural Natural Resources of South Africa 15.

Ter Braak, C.J.F. \& Šmilauer, P., 2009, CANOCO reference manual and user's guide to CANOCO for Windows: Software for Canonical Community Ordination (version 4.5), Microcomputer Power, New York.

Tilman, D. \& El Haddi, E., 1992, 'Drought and biodiversity in grasslands', Oecologia 89, 257-264.

Van Oudtshoorn, F., 1999, Guide to grasses of South Africa, Briza Publications, Pretoria.

Van Wyk, B. \& Van Wyk, P., 1997, Field guide to trees of southern Africa, Struik Publishers, Cape Town.

Van Wyk, E., Cilliers, S.S. \& Bredenkamp, G.J., 2000, 'Vegetation analysis of wetlands in the Klerksdorp Municipal area, North West Province, South Africa', South African Journal of Botany 66, 52-62.

Wood, J., Low, A.B., Donaldson, J.S. \& Rebelo, A.G., 1994, 'Threats to plant species diversity through urbanisation and habitat fragmentation in the Cape Metropolitan Area, South Africa', in B.J. Huntley (ed.), Botanical diversity in southern Africa, pp. 259-274, Creda Press, Cape Town. PMid:7941307 